Further studies are proceeding on the effects of inosine in combination with hypothermia for more prolonged ischaemic surgery and for preserving the cadaver kidney for transplantation.

We thank the Joint Research Board, St Bartholomew's Hospital, and St Peter's Trust for financial support, and the department of nuclear medicine, St Bartholomew's Hospital, for the renographic studies.

${ }^{1}$ Fernando, A R, et al, Lancet, 1976, 1, 555.

${ }^{2}$ Fernando, A R, et al, Transplantation, 1977, 23, 504.

${ }^{3}$ Fernando, A R, et al, European Urology, 1977, 3, 355.

${ }^{4}$ Linquette, M, et al, Lille Médical, 1976, 12, suppl, p 265.

${ }^{5}$ Britton, K E, in Medical Radionuclide Imaging, vol II, p 401. Vienna, International Atomic Energy Agency, 1977.

(Accepted 30 March 1978)

Department of Urology, St Bartholomew's Hospital, London EC1A 7BE

J E A WICKHAM, MS, FRCs, senior consultant urological surgeon

A R FERNANDO, MD, research registrar

W F HENDRY, CHM, FRCS, consultant urological surgeon

L E WATKINSON, medical laboratory technician

H N WHITFIELD, MCHIR, FRCS, chief assistant

Department of Chemistry and Biochemistry, Medical College of St Bartholomew's Hospital, London EC1A 6BQ

D M G ARMSTRONG, PHD, lecturer

J R GRIFFITHS, MB, DPHIL, lecturer

\section{Permanent insulin-dependent diabetes mellitus after congenital temporary diabetes mellitus}

Congenital temporary diabetes mellitus is a rare syndrome occurring in the first.six weeks of life. It differs from classical juvenile-onset diabetes mellitus in infants in that it is transient, with complete recovery after three to four months. There is usually no family history of diabetes mellitus. The affected infants are underweight, yet full-term, with severe dehydration. The neonate has a "peculiar pallor and lined, aged appearance associated with a remarkably open-eyed alert facies." Two to three weeks after birth glycosuria and hyperglycaemia, often severe, are noted; but ketosis is usually absent. Such children are insulin sensitive, requiring on average 8 units per day. Some patients have been followed-up for as long as 25 years ${ }^{2}$ with no evidence of recurrence of the diabetes mellitus. This report describes for the first time the development of permanent insulin-dependent diabetes mellitus in a young woman who had had congenital temporary diabetes mellitus as an infant. ${ }^{1}$

\section{Case report}

The patient has previously been described in detail by one of us (AJK)' in a report of four cases of congenital temporary diabetes mellitus (case 3). ${ }^{1}$ In summary, she was born at 36 weeks' gestation weighing $2 \cdot 13 \mathrm{~kg}$. Soon after birth she developed weight loss, fever, and dehydration; and on the 34 th day glycosuria was detected without acetonuria. Diabetes mellitus was confirmed by a blood glucose level of $44.5 \mathrm{mmol} / 1(800 \mathrm{mg} / 100 \mathrm{ml})$. The glycosuria persisted for four weeks, though soluble insulin, 4-7 units daily, was required for only 17 days. Subsequent glucose tolerance tests at seven months and two years after birth gave normal results. The patient was later admitted to hospital for minor surgery at the ages of 9 and 15 years, and neither glycosuria nor ketonuria was detected. Her mental and physical development were entirely normal.

In July 1976, when she was 18 years, the patient was referred with a lesion on the right lower shin (see figure) that had been present for two years. Professor Hare diagnosed necrobiosis lipoidica diabeticorum. ${ }^{3}$ On inquiry she gave a four-month history of thirst and polyuria. There was no family history of diabetes or other autoimmune disease. Two per cent glycosuria (Clinitest) was found but no acetonuria, and a glucose tolerance test confirmed diabetes mellitus with values at $0,30,60,90$, and 120 minutes of $9 \cdot 5,16 \cdot 0,15 \cdot 6,14 \cdot 7$, and $13 \cdot 5 \mathrm{mmol} / 1(171,288,281,265,249 \mathrm{mg} / 100 \mathrm{ml})$ respectively. The patient's HLA type was A2, A9, B12, and her serum was negative for pancreatic islet-cell antibodies (ICAb). There was no evidence of infection or hyperadrenalism.

Treatment was started with insulin zinc suspension, 20 units daily, and during the next year her diabetes was satisfactorily controlled. The insulin

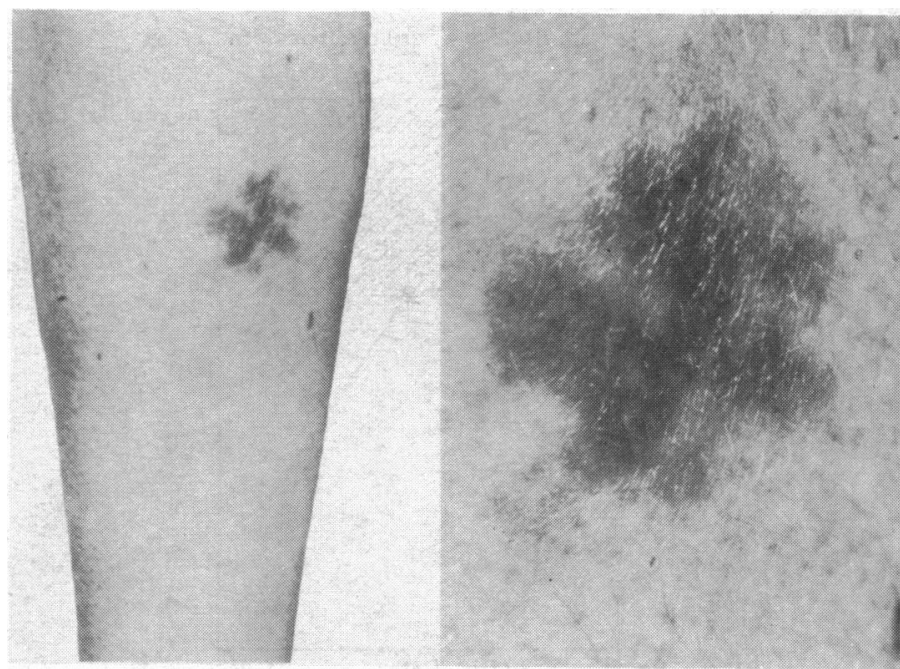

Irregular area on right shin (left), shown on close-up (right) to be dull red with numerous yellow foci within it, consistent with necrobiosis lipoidica diabeticorum

requirements then increased, and for the past nine months diabetes has been controlled on 48 units of Monotard MC daily. There has been no change in the appearance of the necrobiosis diabeticorum.

\section{Comment}

This is the first report of a patient with congenital temporary diabetes mellitus ${ }^{1}$ proceeding to develop permanent insulin-dependent diabetes mellitus. This patient had the prediabetic lesion of necrobiosis lipoidica diabeticorum, ${ }^{3}$ which was present for two years before her diabetes mellitus was diagnosed.

The cause of congenital temporary diabetes is unknown but poor placental function may cause delayed fetal $\beta$-cell maturation, though other factors have been tentatively incriminated, such as infection, intracranial haemorrhage, dehydration, hyperadrenalism, and a "flat" maternal glucose tolerance response with consequent failure to stimulate fetal insulin production. ${ }^{4}$ This patient did not have ICAb or the HLA type usually associated with insulin-dependent diabetes mellitus, ${ }^{5}$ and the underlying cause of this particular insulin-dependent diabetes mellitus may be different.

We thank Professor P J Hare for his dermatological opinion and original referral, Dr W J Irvine for ICAb testing, and Dr A White for HLA typing.

${ }^{1}$ Hutchison, J H, Keay, A J, and Kerr, M M, British Medical fournal, $1962,2,436$.

2 Cornblath, M, and Schwartz, R, in Disorders of Carbohydrate Metabolism: Major Problems in Clinical Pediatrics, vol 3, p 105. Philadelphia, Saunders, 1966

${ }^{3}$ Hare, P J, British Fournal of Dermatology, 1965, 67, 365.

4 Gentz, J C H, and Cornblath, M, in Advances in Pediatrics, vol 16, p 345. New York, Year Book Medical Publishers, 1969.

${ }^{5}$ Irvine, W J, et al, Diabetes, 1977, 26, 138.

(Accepted 30 March 1978)

Diabetic and Dietetic Department, Royal Infirmary, Edinburgh EH3 9YW

I W CAMPBELL, MRCP, senior registrar

D M FRASER, MRCP, senior registrar

L J P DUNCAN, FRCPED, consultant physician

Medical Paediatric Department, Western General Hospital, Edinburgh EH4 2XU

A J KEAY, FRCPED, consultant paediatrician

\section{Correction}

\section{Gold lung}

In the short report by $\mathrm{Dr} D \mathrm{~W}$ James and others (10 June, $p$ 1523) the values for $T_{L}$ CO in the paragraph headed "Progress" should have read " $3.91 \mathrm{mmol} / \mathrm{kPa} / \mathrm{min}$ (predicted $8.83 \mathrm{mmol} / \mathrm{kPa} / \mathrm{min})(11.7 \mathrm{ml} / \mathrm{mm} \mathrm{Hg} / \mathrm{min}$ (predicted $26.4 \mathrm{ml} / \mathrm{mm} \mathrm{Hg} / \mathrm{min})$ )." 